European journal of American studies

Special Issue: May 68

\title{
Recalling the Netherlands in 1968: Trendsetter or Follower?
}

Rob Kroes

\section{(2) OpenEdition \\ Journals}

Electronic version

URL: https://journals.openedition.org/ejas/2902

DOI: $10.4000 /$ ejas.2902

ISSN: 1991-9336

Publisher

European Association for American Studies

\section{Electronic reference}

Rob Kroes, "Recalling the Netherlands in 1968: Trendsetter or Follower?", European journal of American studies [Online], 3-2 | 2008, document 5, Online since 08 September 2008, connection on 08 July 2021. URL: http://journals.openedition.org/ejas/2902 ; DOI: https://doi.org/10.4000/ejas.2902

This text was automatically generated on 8 July 2021 .

Creative Commons License 


\title{
Recalling the Netherlands in 1968: Trendsetter or Follower?
}

\author{
Rob Kroes
}

\section{Introduction}

1 In 1966 in Amsterdam the royal wedding between Crown Princess Beatrix and the German prince Claus von Amsberg took place. Amsterdam had been the center of playful street happenings, demonstrations and clashes with the police in the preceding years, in the tentative early stages of a youthful revolt against established patterns of authority. The royal wedding served to provide a focus for the concentrated expression of discontent. Disturbing the peaceful progress of a public event that many felt had been foisted on a city long known for its republicanism and unruliness was for many the aim of the day. While the royal cortege was heading toward the West church, smoke bombs clouded the street and made for iconic photographs that put the Netherlands on the map of international protest which the 1960s have been remembered for ever since. As an Amsterdam student and an editor of the satirical student weekly Propria Cures I found myself among the crowds lining the street on that day, and to my own amazement found myself shouting, along with many others, the slogan of the day: "Republic, Republic." I remember the exhilaration of the moment, the carnivalesque force of it all causing normal social forms of restraint to briefly disappear. As more of an observer than a participant in mass events, though, it did not take me long to look back and try to find a more objective perspective on those times. This essay is a continuing part of that process. ${ }^{1}$

2. Living Dangerously in Amsterdam

2 A well-known quip commonly attributed to Heinrich Heine has it that if the world comes to an end, the Netherlands is a good place to be, since history there only happens at a fifty-year delay. If 1968 was the year of living dangerously, we may therefore well ask ourselves the question whether the Netherlands sailed blithely untouched through that year, or whether indeed it made its own contribution to the excitement of the day. Could we argue that, yes, the Netherlands uncharacteristically set certain trends that resonated internationally and that culminated in 1968, or rather 
that the country was at best a dedicated follower of fashion? As one who had Dutchness inescapably thrust upon him at birth and who grew up in a culture known for its ageold traditions of compromise and accommodation, I am tempted to negotiate my way out of this stark binary option and say that the Netherlands was both, trendsetter and follower.

3 And let us face it: this is probably the proper position to take, not only for the case of the Netherlands, but more generally when we return to the turmoil of the late sixties and try to make sense of a picture that is truly international, a picture of forces and trends, of flows of information and communication, that transcends the context of individual nations and countries. Collectively caught in a maelstrom of modernization, nations could briefly bob up and catch the attention of others, suggesting ways forward and contributing to the social whirl. Now this nation, than that, set an example that inspired others. National capitals or other metropolitan centers took turns as focal points for the international congregation of a budding bohemia in the formative years of an emerging international youth or, for that matter, counter-culture. Thus, in the 1950s, Paris, or rather Saint-Germain des Prés, was the magnet that drew an international flock of writers, musicians, photographers, plus an admiring coterie of followers, collectively engaged in transcending the boredom and constraints of a reigning Cold-War consesnsus culture. Then, in the early 1960s, London, or should we say Carnaby Street, took over this role of a center where the action was. In the late 1960s, San Francisco, or better the Haight-Ashbury district, drew the international gaze of those in search of a new life style. Certainly, influence and emulation are an important part of the story, but they could only play their part because all those involved were facing similar challenges and tensions. These in turn were the outcomes of long-term processes of change and social transformation. All Western societies, in Europe and North-America, were equally subject to them.

4 Among those transformative forces, arguably the most important was economic affluence, giving rise to consumerism as a cultural vector. The United States, as the first country to enter this dreamworld of abundance, could thus define the ways in which to enjoy the pleasures of consumerism and mass culture, not only for Americans but also for eager foreign audiences. It could play this pioneering role due to transformations in the media of mass communication. Film and radio, then television, served as channels for the communication of these American versions of the "Good Life." Americanization, then, as one of the forces shaping the pleasures of consumerism for Europeans, is another of the transformative forces at work. Another important transformative force was the working through of the 1940s' baby boom, which resulted in an unprecedented high proportion of young people in all western countries by the early sixties. As they came onto the public stage, they had enjoyed (if that is the word) more education than any generation before them, they had more leisure and money to spend while being able to postpone adulthood and the strictures it normally would bring.

5 My question then is: was the Netherlands late in joining this novel international configuration of structural forces and cultural ferment? Where was Amsterdam in 1968? Was there a spring as in Prague at the time, was there the threat of regime change as in Paris at the time of its "évènements de May," were there signs of a campus revolt as in the United States, with students occupying university administration buildings and smoking the university President's cigars as happened at Columbia University in 1968? It did not quite take Heine's fifty years lapse, but just one year 
before Amsterdam students joined the international fracas when they occupied the administration building of their university. They had clearly taken their cue from events taking place earlier elsewhere. They were followers rather than international trendsetters. Yet at the same time Amsterdam had taken its place as one of the international centers for an international youth culture to congregate, its place - as the local avant-garde had it - of "magic center" where it all happened, where sex, drugs, and rock'n roll were freely available. And rock and roll they did, spending the nights in their numbers around the phallic symbol of the National War Memorial at Dam Square in Amsterdam or in the aptly named Vondelpark, incidentally one of the monuments to the bourgeois imprint that the city had received in the late nineteenth century. Foreign journalists were astounded at the transformation of the Netherlands from a country widely seen in the late fifties as caught in the stultifying patterns of a bourgeois, parochial and inward-looking society to one characterized by libertarianism and tolerance of cultural diversity. If, in the 1950s, socio-economic security had been the guiding value among the parental generation, who vividly remembered the lean years of depression and world war, by the early 1970s the younger generation had abandoned those limitations with glee. ${ }^{2}$ Clearly, if we do not pin ourselves down to the single year of 1968, Amsterdam, and more generally the Netherlands, should be included among those places that gave the history of the turbulent sixties its shape rather than passively receiving its imprint.

3. The Incubation Period

6 In order to get a better sense of the pattern of cultural renewal that came to full bloom in the late 1960s and 1970s, we have to go back to what we may call the incubation period of these changes. Unnoticed and incoherent at first, many trends culminating in the visible changes of the late 60 s had already set in during the 50s, if not before. The immediate response of Dutch society to the challenges of postwar reconstruction had been sought in the restoration of time-honored pre-war political and social arrangements and institutions. Dreams of a new start and a novel dispensation as harbored by elite circles during the war rapidly proved illusionary in the face of the urgent agenda set by postwar conditions. The national economy had to be restored, the call for decolonization from the Dutch East Indies to be faced, and the place of the Netherlands in the world to be redefined. Following the trauma of German occupation the Netherlands bid farewell to its cherished neutrality and joined the Western alliance in the common defense against the Soviet threat. It also joined various European programs of economic and political cooperation, some under Marshall Plan auspices, others originating in Europe. One further challenge was to turn the Netherlands into an industrial country on a par with its neighbors. As late as the 1930s the Netherlands had lagged behind the others, with some 60 per cent of its population employed in agriculture. Thus, industrialization and the attending process of urbanization added to the transformations that all countries in the West were undergoing.

7 Faced with these many challenges, the Dutch post-war return to its traditional and time-honored political ways may be understandable. In what political scientist Arend Lijphart has called the politics of accommodation the Dutch had developed a flexible system able to cope with and incorporate a variety of contending interests and forces as they arose through its political history. In the continuing emancipation of segments of society, such as various religious groups or an emerging working class, all clamoring for a place at the political table, a characteristic Dutch political pattern took shape, commonly known in the vernacular, as well as in later comparative political science 
literature, as Verzuiling, or pillarization. Each segment was given sufficient space to organize itself, in political parties, in labor unions or employers' organizations, through setting up its own broadcasting corporations and its own newspapers, or even its own leisure time organizations such as sports clubs. Thus, social and cultural life in the Netherlands proceeded along highly compartmentalized lines under the paternalist guidance of the various segmented elites. Only at the elite level did these various pillars find a common roof, where the politics of accommodation found its expression in ongoing compromise and negotiation. Altogether it was a flexible system, open to new interest groups as they arose, flexible in its accommodation of difference and diversity. No such system, of course, could have survived without a shared political culture, a shared willingness to pre-empt social divisions, if not social explosions, by the timely incorporation of groups claiming access to and inclusion among the policy-making elites. There had been tensions and conflicts, episodes of high political drama, but they always ended with ruling elites giving in and making way for clamoring voices outside the door.

8 The restoration of this system in the immediate post-war years served the Netherlands well in the turbulent period of its social and economic reconstruction. It helped the Netherlands on its way to unprecedented prosperity in the late 1950s, seen as a collective endeavor, with all groups assuming their part of the burden, with the various segmented labor unions supporting a policy of low wages to shore up the nation's international competitive strength. Yet, by the late 1950s, tensions had begun to build up. For one thing, organized labor became restive, claiming a fair distribution of the newly-gained national wealth through higher wages. But more generally it turned out that the Netherlands had rapidly burst out of the confining structures of its social and cultural compartments, causing citizens to see the prevailing system of political representation as outdated, as no longer a proper reflection of Dutch society as they experienced it. Some of this tension was the unanticipated outcome of precisely those forms and forces of modernization to which the country had opened up. Urbanization had worked to break up the communal bonds that had kept so many safely harbored in the confines of their various pillars. Mass education had widened the horizons of many, weakening their willingness to be the meek sheep in flocks benevolently herded by paternalist leaders. Mass culture, in its American vein, had worked to change the leisure time pursuits and cultural tastes of younger generations, redefining the quest for self-expression and identity while undermining the established patterns of authority and moral leadership. Most importantly perhaps one new medium of mass communication, television, had worked in unanticipated ways to help people break out of their imposed cultural settings, increasingly felt as a straightjacket. Ironically, in the grand Dutch manner, television had been allowed in on the condition that it be organized under the auspices of the established pillars of society. Thus, entrenched broadcasting corporations, Catholic, Protestant, Socialist and bourgeois-liberal, who had all cut their teeth since the 1920s in radio, each successfully addressing their own flocks while keeping them separate from the others, were now put in charge of television broadcasts. From its introduction in the early 1950s, though, due to limited broadcasting time the public's hunger for this new marvel of communication led to people watching programs irrespective of their denominational auspices. It allowed them, on an unprecedented scale, to enjoy programs as a national audience, weaning them off their parochial habits of cultural consumption. It is hard to say what came first, whether television caused a weakening of social and religious denominations and 
their separate cultures and communities, or whether this would have happened anyway, but certainly during the 1950s this process rapidly picked up speed. People's religious denomination, by the early 1960s, had lost much of its force as a meaningful source of social and political affiliation. Secularization affected all western societies at the time, yet it had its own specific effect in the Netherlands. It created a new critical mass, particularly from among the younger generations, for the overhaul of established institutional structures. A new perspective took hold among vocal minorities who saw the old representative structures as unresponsive, mired in old-fashioned oligarchic ways, in short as suffering from a democratic deficit. Theirs was a need for new cultural directions, inspirations and enthusiasms to fill a void that the 1950s had left in their wake.

9 Was this the harbinger of just another episode of drama, to be deftly handled by the ruling elites, and solved through co-optation and accommodation? One author in particular, American historian James Kennedy, in a book about the Netherlands during the 1960s, argues his case in this vein. ${ }^{3}$ He has a keen eye for the quest for cultural renewal that moved those who felt alienated from the stifling conventions of everyday life in the Netherlands. He gave his book the title of New Babylon Under Construction, after Constant Nieuwenhuys's early 1960s design of an urban utopia where a "new man," the homo ludens, would be set free by technological advance from the constraints of labor to lead a life of sheer playfulness and creativity. Constant, to use his artist's name, had gained a reputation as one of the founders of the avant-garde COBRA group and of the Situationists. A 1965 exhibition in The Hague would give his utopian ideals an international impact. In the Netherlands his ideas were picked up by the Amsterdam Provo movement, and they set the tone and provided a language for many of the public happenings organized by the countercultural pioneers. "Ludiek" was the word they used for their style of public action, a word derived from Huizinga's "homo ludens," and best translated as playful, or carnivalesque.

10 Kennedy illustrates convincingly the widely shared sense among political elites in the Netherlands that renewal was in order, that "the times they were a-changing" and that they had to go with the flow. Indeed, during the 1960s, there were explosive moments, a few political heads did roll, yet overall the system proved flexible and accommodating. By the late 60s and early 70 s institutional structures and styles of life had changed beyond recognition. New political parties, giving voice to alienation and dissent, had allowed extra-parliamentary commotion to enter parliamentary politics. A self-styled "New Left" group had successfully entered the Labor Party and put their programmatic imprint on it. University government, seen as oligarchic and unrepresentative, had caved in to a point where students were now represented at every university administrative level, so that briefly, in the early 1970s, they collectively decided on grades given to their own academic work. Police, wielding truncheons and cracking a few skulls in the mid-1960s, themselves started growing their hair long, looking like hippies in uniform. The media, radio as well as television and film, now used language and showed images unthinkable in the petty-bourgeois climate of the 1950s. These changes had all resulted from borderline experiments during the 1960s, causing uproar if not retaliation when they were first tried. Yet time and again, the border proved to be a moving border, yielding to pressure rather than resisting it. Taking this longer view, though, is like looking at the 60 s with the wisdom 
of hindsight, like conflating long-term outcomes with the hopes and excitement of each passing moment as the 60 s unfolded.

4. 1966 , not 1968

11 Let me therefore pause and look at some of those moments. If there is one annus horribilis (or memorabilis, for that matter) in the Dutch 1960s, it is 1966, not 1968. 1966 is the year where separate streams of counter-cultural ferment as well as more traditional working-class action came together to cause an explosion that at the time may well have seemed to augur the collapse of an entire regime. Hopes were high, and so, in different circles, were fears, as the Netherlands put itself on the international map of 1960s turbulence. From then on it could draw an international gaze that previously, from the late 50s, had been focused on Britain with its Campaign for Nuclear Disarmament and its New Left Review. Those were the years when C. Wright Mills could write his famous "Letter to the New Left," deploring the absence of an agent of social and political change in the United States, while coining a name that shortly afterwards American students would pick up as a badge of honor. The gaze would then redirect itself and look for inspiration to the America of the Civil Rights movement, to the student New Left, and to Berkeley at the time of its Free Speech Movement. Words traveled along with television images and were picked up in the Netherlands, words such as "happening," "sit-in," "teach-in" and the like and were adopted there along with the forms of action they described.

12 Among the various components making up the explosive mixture of the year 1966 were the Provos, arguably the most colorful, certainly the most articulate group of participants. There was nothing provisional about the Dutch Provos, rather something improvisational. They were out to explode the stultifying mould in which Dutch society, including the fixed rituals of artistic life, was cast. They set out to do so through the playful provocation (hence their nom de guerre of Provo) of the established order, in staged public performances which they called happenings. There were echoes here of the American Fluxus movement inspired by American musician and designer George Maciunas, echoes also of the first happening organized in New York in 1959 by Allan Kaprow. The first happening in Amsterdam, called "Open the Grave,"was organized by Simon Vinkenoog, an experimentalist poet who served as a personal trait d'union with the Paris cultural scene of the 1950s and its international mixture of jazz, beatniks, and drugs. Provo, set up in 1965, took its name from a scholarly dissertation about the subculture of Dutch youngsters who, like Germany's Halbstarken or England's Teddyboys, were mostly of working-class background. They were the first instance of an adoption of the new culture of consumption for developing an early version of youth culture, intellectually inarticulate, and meant to provoke parental and social strictures, upsetting public order and seeking clashes with the police. Provo recognized the potential for social renewal and meant to imbue it with a more articulate program for social action, giving direction to the aimless energies of the budding youth culture in the Netherlands. The year 1966 would first show up the explosive potential of this new alliance.

13 One occasion was the royal wedding in Amsterdam. Crown Princess Beatrix had chosen a German prince, Claus von Amsberg, for her husband. As a young man he had served in the German Wehrmacht during the war. This was enough to trigger widespread resistance to his becoming Prince of the Netherlands. War memories and anti-German feelings were particularly acute in Amsterdam which had lost most of its Jewish 
population during the war. Yet, unwisely, the government insisted on having the wedding take place in Amsterdam. The day would be one of massive clashes between hordes of mostly young people and the police. Provo managed to catch the international limelight by setting off a few smoke bombs while the royal cortege was heading towards the West Church. Photographs of the smoke-filled street would make front pages internationally.

Shortly afterwards a strike by construction workers, a classic union-based conflict over wages, would once again provoke the nervous city government to over-react. Rapidly escalating pitched street battles with the police briefly assumed the contours of a revolution, threatening the total collapse of political order. Police reinforcements had to be brought in from outside Amsterdam to quell the uprising. Heads had to roll. Both the city mayor and the chief of police were sent packing. The central government set up an advisory committee of wise men to study the clashes and come up with suggestions for making the city government of Amsterdam more responsive to social unrest. From then on, to put it succinctly, the Amsterdam police would grow its hair long. The first test of this new attitude and approach would be the student occupation of the University of Amsterdam's administration building in 1969. It was handled in an exemplary way by the Amsterdam city authorities and police.

The large population of Amsterdam students had played its role in the ferment of the preceding years. Some were among the Provo leadership, others played a role in raising the level of popular culture literacy and awareness among youngsters through a highly influential and playful weekly, called Hitweek. It aimed at instilling a sense among youngsters that they formed part of an international youth movement in a belief that it held the promise to make the world anew. They gave expression and direction to a widely shared excitement that change was in the air. Yet, to the extent that there was a recognizably distinct student movement in the Netherlands, it was relatively late in joining the enthusiasms of the time for playfully turning universities into more democratic institutions, allowing for greater participation of students in university affairs. With the Amsterdam sit-in action they briefly joined an international pattern. It would not be long before their style of politicization adopted the wooden language of a facile and vulgar version of neo-Marxism. Never, though, would they go as far in directions of violent action as the American Weatherman faction or similar extremist groups in Germany and Italy. Following the democratization of university structures they mostly withdrew into activist cells exerting a veto power over academic policies rather than creatively coming up with new alternatives.

5. Conclusion

16 In the early seventies many of the high hopes of the preceding years had died. Yet many battles had been won. There was a lasting heritage of the liberationist enthusiasms of the sixties. Many sub-cultural life-styles and issues had become commonly accepted, turning the Netherlands into a safe haven for all those who had acted on behalf of women's issues, gay rights, soft drug use, frontal nudity on television, and the like. Yet the excitement had gone. In politics there was a return to business as usual, to bread-and-butter issues, to the harsh reality of coping with the oil shock of 1973, and more generally with predictions of the world coming to the end of its resources. But never did the gains of the 1960s lead to the sort of massive political reaction as in the United States where under successive conservative administrations attempted to put the genie of the sixties back into the bottle. No such attempts at 
turning the clock back can be seen in the Netherlands. Never was liberalism, or libertarianism for that matter, turned into the dreaded L-word the way it was in the United States.

Emeritus professor of American Studies, Amsterdam University

\section{NOTES}

1. In the mid-seventies I compared the experience of protest in Western countries in New Left, Nieuw Links, New Left: Verzet, beweging, verandering in Amerika, Nederland, Engeland (Alphen aan de Rijn/Brussel: Samsom, 1975 [The New Left Compared: Resistance, Movement, and Change in The United States, the Netherlands, and England]. This essay was originally written for an informal symposium entitled 'The Year of Living Dangerously,' convened by Chris Bigsby at the University of East-Anglia in Norwich in 2007.

2. Ronald Inglehart, The Silent Revolution: Changing Values and Political Styles Among Western Publics (Princeton: Princeton University Press, 1977) 38, 104.

3. James C. Kennedy, Nieuw Babylon in aanbouw: Nederland in de jaren zestig (Amsterdam/ Meppel: Boom, 1995)

\section{AUTHOR}

\section{ROB KROES}

Emeritus professor of American Studies, Amsterdam University 